\title{
Adoption of e-payment system to support health social security agency
}

\author{
Mochammad Fahlevi ${ }^{a^{*}}$ and Nouf Sahal Alharbi ${ }^{\mathrm{b}}$
} \author{
C H R O N I C L E \\ Article history: \\ Received: April 12, 2021 \\ Received in revised format: June \\ 21,2021 \\ Accepted: July 14, 2021 \\ Available online: July 16, 2021 \\ Keywords: \\ e-payment \\ Perceived ease of use \\ Perceive usefulness \\ Attitude \\ Intention \\ Health insurance
}

${ }^{a}$ Management Department, BINUS Online Learning, Bina Nusantara University, Jakarta, Indonesia 11480 ${ }^{b}$ Department of Health Administration, College of Business Administration, King Saud University, Riyadh, Saudi Arabia \begin{abstract}
A B S T R A C T
The development of the existing information technology era has helped the performance of BPJS more and more. The application of information technology in the work environment includes meeting the efficiency level of time and cost. The use of the internet also makes it easier for BPJS to access their services to the public and the search for new members is made easier. The world of ICT does provide a big role in society. In Indonesia itself, the prospect of ICT in future life has provided a lot of welfare for the people of Indonesia. This research was conducted in Indonesia, the sampling in this study was conducted in Jakarta. The results of research conducted showed that all hypotheses proposed in this study were accepted, especially the biggest influence was found on the attitude variable towards intention in the use of the BPJS e-payment system in Indonesia. Electronic Payment System (EPS) BPJS strives to create a social security system that is transparent and accountable to BPJS Employment participants.
\end{abstract}

\section{Introduction}

In order to facilitate the payment of contributions made by companies to BPJS, the Electronic Payment System (EPS) was introduced as a new payment system from BPJS (Health Social Security Agency) (Ratnawati, Cokrohadi, \& Kholis, 2020). This EPS system replaces the Virtual Account (VA) system which was previously used by the company to pay BPJS contributions. The replacement of the payment system from VA to EPS was carried out to fulfill the mandate of Law no. 24 of 2011 concerning BPJS which requires that his party as the agency managing the labor social security fund must separate BPJS assets from the Social Security Fund. With the Electronic Payment System (EPS), BPJS strives to create a social security system that is transparent and accountable to BPJS Employment participants. In addition, the payment of dues is easier because it is separate and depends on what program is being paid (Permana, Wicaksono, Kurniawan, Abdullah, \& Ruchjana, 2021). If previously using VA, the company and BPJS still must coordinate during the process of separating contributions from Work Accident Insurance (JKK), Death Security (JK), and Old Age Security (JHT). Through EPS, the fees paid are in accordance with the program and a self-assessment is carried out by the company itself. That way, the risk of calculation errors and transactions that may occur will be less likely. Through the National Health Insurance Program-Healthy Indonesia Card (JKNKIS) organized by BPJS Kesehatan (Ratnawati et al., 2020), the state is in our midst to ensure that all Indonesians are protected by comprehensive, fair and equitable health insurance. Unlike the case with health insurance, companies that are proven not to have participated in the BPJS Employment program will be subject to sanctions ranging from administration, recommendations for revocation of business licenses to a maximum criminal sanction of 8 years or a maximum fine. In contrast to conventional health insurance, BPJS Employment has several programs that aim to protect and provide security to workers.

* Corresponding author.

E-mail address: mochammad.fahlevi@binus.ac.id (M. Fahlevi)

(C) 2021 by the authors; licensee Growing Science, Canada. doi: $10.5267 /$ j.ijdns.2021.7.007 
Workers who have BPJS Employment will get insurance in their old age. And feel safe in their work because of the work accident insurance program and death insurance program in the event of death not due to work accidents (Yustisia, 2014).

One of the BPJS Employment programs that many workers look forward to is the pension insurance program. This program aims to provide a decent life guarantee for BPJS Ketenagakerjaan participants after retiring in the world of work (Ratnawati et al., 2020). In addition, for workers engaged in construction, there is a construction service program, namely construction work planning consulting services, construction work implementation services, and construction work supervision consulting services that are interesting to follow. After the company registers its employees as BPJS Employment participants, another important process is to pay monthly contributions. The easiest and recommended way is to use the Electronic Payment System (E-Payment System). Mobile technology has transformed the global banking and payments industry by providing convenient payment channels. The impact is greater for developing countries due to the existence of a large untouched customer base consisting of unbanked customers (Chawla \& Joshi, 2020). In Indonesia, this opportunity has attracted many new players, including start-ups, to start with e-payment system services. This has resulted in players from the telecommunications, banking and online retail industries starting to do business with their own e-payment services. E-payment have the same functions as physical wallets. Money in e-payment systems can be loaded using a debit/credit card or net banking, which can then be used to make payments to people/merchants (Bagla \& Sancheti, 2018). This transaction can be through multi-channel such as consumer to consumer, consumer to business, consumer to machine and consumer to online (Shin, 2009). ICT (Information and Communication Technologies) or in Indonesian better known as Information and Communication Technology, is an understanding that provides coverage in all aspects of technical equipment in providing information, conveying information, and the processes of the technology (Fahlevi, 2021c). There are two things that are very important in the world of ICT, namely technology in information and technology in communication. Everything related to information technology in the scope of the process, the use of assistive devices, manipulation, and how information is managed (Djakasaputra et al., 2021).

The development of the existing information technology era has helped the performance of BPJS more and more. The application of information technology in the work environment includes meeting the efficiency level of time and cost (Fahlevi, 2021b). The use of the internet also makes it easier for BPJS to access their services to the public and the search for new members is made easier. The world of ICT does provide a big role in society. In Indonesia itself, the prospect of ICT in future life has provided a lot of welfare for the people of Indonesia. The field that is following the rapid developments with ICT is the world of economy (We Are Social \& Hootsuite, 2020). Its use includes the use of ICT to support small and medium enterprises to become more productive. This can be seen in business affairs that link communication and information technology as use in electronic commerce (Naim \& Lenkla, 2016). Trade that uses the use of the internet communication network is referred to as the world of E-Commerce (S. Sahir et al., 2021). The application of E-Commerce in the banking world is also commonly recognized by the existence of transactions and banking applications through internet banking or E-wallet (Kumar et al., 2018). ICT has given impetus to traders. Not only trading and banking are made easier, but basically everything now no longer needs to be done in the old or traditional way. Utilizing the development of existing communication technology means that we work in a practical way and leave manual habits (Madan \& Yadav, 2016). Technological developments have created new trends in banking transactions, one of which is e-payment systems. E-payment system as part of E-banking is widely understood as the ability to take advantage of mobile phone facilities to make online payment transactions (Sahir et al., 2021). Not surprisingly, the rapid development of e-payment systems due to the presence of smartphones has been able to answer the needs of modern society that promotes mobility and creates ease of transaction services today. In other words, epayment systems are growing because these services are able to provide flexibility and practicality of transactions (Liu et al., 2015) mentioned that it has been more than 20 years since technological developments in mobile payment systems have been very helpful in initiating and shaping new innovations (Hatzakis et al., 2010). The growth of e-payment in Indonesia itself has been increasing since 2012 until now (Istan et al., 2021).

\section{Literature review}

\subsection{Perceived ease of use}

Perceived ease of use is a belief about the decision-making process in using information technology. A person's perception of the ease of using information technology shows the extent to which the person believes that using a technology can facilitate the completion of his work/task. This perception will then affect the user's behavior (Ramadan \& Aita, 2018). According to (Madan \& Yadav, 2016), Perceived ease of use is the extent to which a person believes that using information technology requires less effort. According to Yousafzai et al. (2003) The level of individual trust refers to the belief that an information technology is not difficult to use, easy to understand and does not require special skills to operate it (Fahlevi, 2021a). Cao et al. (2018) said that perceived ease of use can be measured through several indicators, including: easy to learn, easy to control, easy to understand, flexible, easy to implement and easy to use. Meanwhile, according to Sreelakshmi and Prathap (2020) explained that perceived ease of use can be measured based on how the system is able to support operations, provide actual information, reduce error rates, be easy to operate and whether the system requires other additions or not. equipment support. There are many models discussed in the literature to predict user behavior in adopting an innovation such as TAM, UTAUT, theory of reasoned action (TRA) and theory of planned behavior. The TAM model shows how users receive and use technology. TAM is one of Ajzen and Fishbein's most influential TRA extensions and replaces many TRA attitude measures with two measures of technology acceptance - ease of use and usability. Perceived ease of use refers to the extent to which potential users expect technology to provide convenience in their business (Davis, 1989). These factors determine the user's attitude towards the use of technology. In addition, the model shows that perceived ease of use affects attitude and intention in using 
a technology (Chawla \& Joshi, 2020). TAM suggests that when users are faced with a new technology, several factors determine their decision about how and when they will use it.

\subsection{Perceived usefulness}

Perceive usefulness is defined as the individual's perception of using new technologies that can improve their performance (Davis, 1989). Applying this definition to the context of an e-payment system is that its usefulness refers to the extent to which consumers believe using an e-payment system as a medium will improve their performance or productivity, thereby improving the outcome of their shopping experience (Cao et al., 2018). Perceived usefulness is related to the outcome of the shopping experience. Detailed information, accessibility, and speed, as well as the availability of cheap and convenient purchases, are often cited as the main benefits of e-payment systems (Khalifa \& Limayem, 2003). For experienced internet users who are busy during normal shopping hours, the accessibility and speed of shopping may be very useful features. Perceived usefulness of using technology is enhanced when a person can operate the system to perform a task without difficulty or hindrance (Davis, 1989). Customer perceptions of the usefulness of using technology are supported by several factors: a. the features offered by the technology; b. the value of the technology mark (prestige) obtained by the customer; and c. supports advanced features. In addition, customers believe that technology will significantly help improve the results of their work (Davis, 1989). The customer's perception of the usefulness of technology is measured by several factors: a. uses include providing benefits and increasing productivity; $b$. effectiveness, where technology can increase effectiveness and improve the quality and quantity of work. e-payment system that has benefits, then the consumer is likely to use the system. On the other hand, if they believe that the system is useless then they will leave it.

\subsection{Attitude}

Satisfaction Attitude towards adoption is a cognitive process that describes a prospective adopter's positive or negative attitude about adopting a foreign technology. As established by the theoretical framework of Theory of Planned Behavior (Ajzen, 1991), attitude towards a behavior is determined by the relevant internal beliefs. After reviewing the relevant literature (Kai-Ming Au \& Enderwick, 2000). While previous research studies have examined technology adoption in the context of mobile banking (Lee et al., 2010) and mobile payments, not many studies exist on e-payment systems and particularly the Indonesian context. Several previous studies have tried to examine the causal relationship between the antecedents that affect attitudes (Singh et al., 2017) and intention (Madan \& Yadav, 2016) to adopt an e-payment system. This study proposes a comprehensive model to examine the influence on attitudes and intentions. The use of attitude variables in this study aims to provide several contributions. The results of this study can assist e-payment system service providers in identifying and prioritizing relevant factors in shaping user attitudes and intentions to adopt e-payment systems. Given the existence and importance of technology, attitudes are relatively universal towards technology, it is not surprising that there has been no further research in this field, especially regarding e-payment systems by combining several variables as in this research model. Most investigations into attitudes toward technology specifically involve computers and information technology (IT), not technology in general. While many people today view IT as a specific tool or set of tools that can help them, technology in general is more ambiguous and abstract making it more difficult to explain relationships, especially with regard to attitudes towards technology adoption (Chawla \& Joshi, 2020).

\subsection{Intention}

Behavioral Intention to Use is a behavioral tendency to continue using a technology (Casaló et al., 2020). BI refers to the intention of effective use by consumers of future products or services (Venkatesh et al., 2003). Meanwhile, according to Arts et al. (2011) is the desire to keep using, as well as the desire to motivate other users. According to Fahlevi (2020), indicators from BI are Willing to use the system in the future, recommending others to use the system, Using a fun system. Meanwhile, according to Huang and Kao (2015), indicators of behavior intention are repurchasing intentions, positive word-of-mouth communication, and service quality. Behavioral intention as a measure of the strength of an intention to perform certain behaviors, especially the use of information systems (Shittu \& Gamabri, 2013). Intention to use is a behavioral tendency to continue using a technology. Many marketers have difficulty when researching the adoption of innovations, because often consumers who have behavioral intentions do not always translate their behavioral intentions into usage behavior (Adila et al., 2020). (Arts et al., 2011). While the intention to continue is a mental condition that describes a person's decision to perform the same behavior at this time and can be compared with the intention to repurchase in marketing (Azam, 2015). In this study, behavioral intention refers to the intention to continue using or continuing a system. Intention to keep using or continuance intention is a strong intention to continue to use a system in this study is to use (Chen, 2012). Continuing intention has been used frequently in a variety of contexts to predict continued behavior (Lin \& Chen, 2012). Previous literature concluded that sustainable use is not only a continuation of adoption decisions. In other words, certain influencing factors in adoption studies may change or lose their impact in continuing intention studies, and other new factors may emerge. Therefore, this study uses a model based on UTAUT and not a model based on expectation confirmation theory (ECT). Behavioral intention will be measured by intention, prediction, and planned use. In the UTAUT model, behavioral intention (BI) has a positive and strong influence on usage behavior (Venkatesh et al., 2003).

\subsection{Research framework}

Based on a review of the theoretical foundations and previous research, a framework of thought in this study can be prepared. 


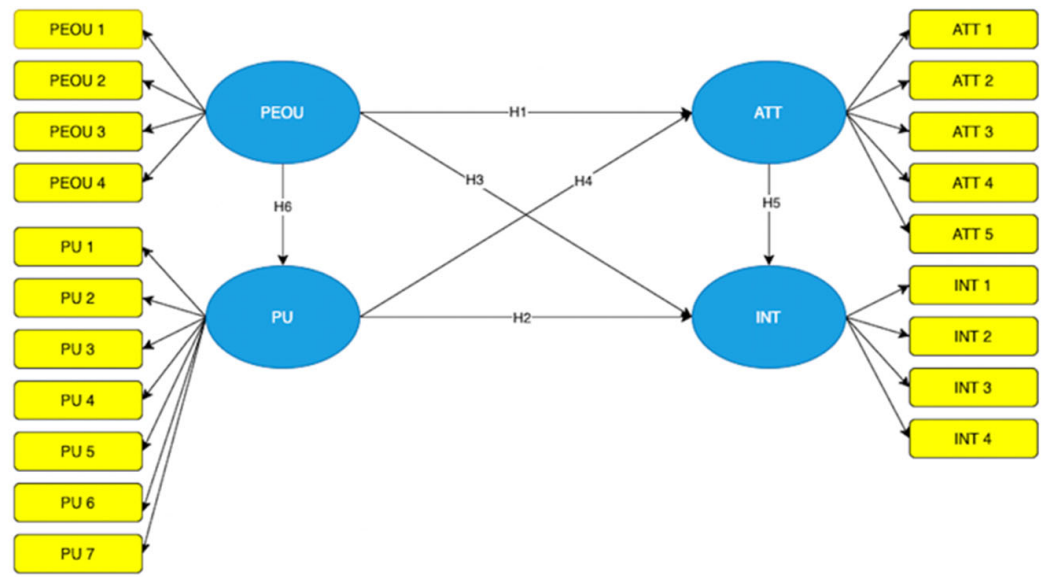

Fig. 1. Research Framework

\section{Methodology}

This study uses quantitative research methods, so that the data collected are numbers that will be analyzed using statistics (Saunders et al., 2009). This quantitative method uses the logic of deductive thinking, namely from general to specific, from a general two-step flow of communication applied to the variables of intention and attitude as the object of research. As a quantitative research, this research is also independent, where there is a distance between the researcher and the object being studied. This research is a basic research, namely pure research or basic research that has a scientific research objective to improve scientific theories and improve understanding or prediction of business or other phenomena. This type of research is quantitative research with SmartPLS 3 analysis tool as a statistical tool to find information about the influence between variables in this study.

\subsection{Measurement}

In operational variables, the dimensions and indicators used to measure the research variables are shown, namely exogenous, intervening, and endogenous variables.

Table 1

Measurement

\begin{tabular}{|c|c|c|c|}
\hline Construct & Indicators & Source & Scale \\
\hline \multirow[t]{5}{*}{ Attitude (ATT) } & I don't think I need anyone else's help in using a e-payment system (ATT1) & \multirow{5}{*}{$\begin{array}{l}\text { Davis (1989) and } \\
\text { Venkatesh et al. } \\
(2003)\end{array}$} & \multirow[t]{5}{*}{ Likert Scale } \\
\hline & I believe the features of the e-payment system app are easy to understand (ATT2) & & \\
\hline & I believe learning to use a e-payment system is easy (ATT3) & & \\
\hline & $\begin{array}{l}\text { I am happy with the fact that payments made via e-payment systems require minimum } \\
\text { effort (ATT4) }\end{array}$ & & \\
\hline & $\begin{array}{l}\text { I believe it is easy to transfer money via e-payment system because the steps are quite } \\
\text { practical (ATT5) }\end{array}$ & & \\
\hline \multirow[t]{4}{*}{ Intention (INT) } & I want to make a transaction using a e-payment system in the near future (INT1) & \multirow{4}{*}{$\begin{array}{l}\text { Venkatesh et al. } \\
\text { (2003) }\end{array}$} & \multirow[t]{4}{*}{ Likert Scale } \\
\hline & Very likely I will use my smartphone for payment (INT2) & & \\
\hline & I will use e-payment system often in the future (INT3) & & \\
\hline & I mean to recommend others to use e-payment system (INT4) & & \\
\hline \multirow{5}{*}{$\begin{array}{l}\text { Perceived Ease } \\
\text { of Use (PEOU) }\end{array}$} & I believe the use of the e-payment system application is easy to understand (PEOU1) & \multirow{5}{*}{$\begin{array}{l}\text { Chawla \& } \underline{\text { Joshi }} \\
(2 \underline{0} \underline{2} 0)\end{array}$} & \multirow[t]{5}{*}{ Likert Scale } \\
\hline & I believe learning to use a e-payment system is easy (PEOU2) & & \\
\hline & $\begin{array}{l}\text { I like the fact that payments made via e-payment systems require minimum effort } \\
\text { (PEOU3) }\end{array}$ & & \\
\hline & $\begin{array}{l}\text { I believe it is easy to transfer money via e-payment system as it only requires mini- } \\
\text { mum steps (PEOU4) }\end{array}$ & & \\
\hline & Overall I think the mobile wallet is very easy to use (PEOU5) & & \\
\hline \multirow{6}{*}{$\begin{array}{l}\text { Perceived Use- } \\
\text { fulness (PU) }\end{array}$} & I think using a e-payment system will allow me to complete transactions faster (PU1) & \multirow[t]{6}{*}{ (Singh et al., 2017) } & \multirow[t]{6}{*}{ Likert Scale } \\
\hline & I believe a e-payment system will be useful for making online transactions (PU2) & & \\
\hline & $\begin{array}{l}\text { I believe using a e-payment system will improve the efficiency of my online transac- } \\
\text { tions (PU3) }\end{array}$ & & \\
\hline & $\begin{array}{l}\text { In my opinion, using a e-payment system will make it easier for me to make online } \\
\text { payments. (PU5) }\end{array}$ & & \\
\hline & I believe e-payment systems improve the quality of online transactions (PU6) & & \\
\hline & Overall, I think using a e-payment system will improve my performance (PU7) & & \\
\hline
\end{tabular}




\subsection{Sample}

This research was conducted in Indonesia, the sampling in this study was conducted in Jakarta. The choice of the city of Jakarta as the sampling location for several reasons, namely, Jakarta is the capital city of Indonesia, Jakarta has the highest per capita income in Indonesia, and Jakarta has the largest population in Indonesia. Technological advances in Jakarta are at the forefront in Indonesia so it can be assumed that technology adoption in Jakarta will be at the forefront in Indonesia. The time used by researchers for this research was carried out from December 2020 to June 2021. The Slovin method is used as the method used in determining the sample of this study. The following is the Slovin formula and its calculations (Nursalam, 2008):

$$
n=N /\left(1+N \times e^{2}\right)
$$

where $N, n$ and $e$ represent the total population, the sample size and error rate, respective. Applying the formula for our case yields $n=286 /\left(1+286(0.05)^{2}\right)=166.76$. In this case we consider $\mathrm{n}=170$.

\section{Results and discussion}

Data collection in the study was carried out by distributing questionnaires to customers and prospective customers of PT. Susan Photo Album which was used as the research sample. Questionnaires began to be distributed to respondents on March 2, 2020, via online using Google Form. The questionnaire has been collected until April 3, 2021. The rate of return of the questionnaire can be seen in Table 2 as follows.

\section{Table 2}

Selection of sample test

\begin{tabular}{lcc}
\hline & Criteria & Sample \\
\hline Number of questionnaires sent & & \\
Total questionnaires that were not collected & & \\
Respondents who have never opened a website & & \\
The questionnaire is broken & & 301 \\
The total questionnaire used as the research sample & \\
\hline
\end{tabular}

Electronic Payment System (E-Payment System/EPS), is a Host to Host payment system for BPJS Employment contributions between banks and BPJS Employment. EPS is provided to facilitate participating companies in monitoring contribution payments.

\subsection{Path analysis}

This path analysis is carried out after examining the outer model, namely validity, reliability, and discriminant tests.

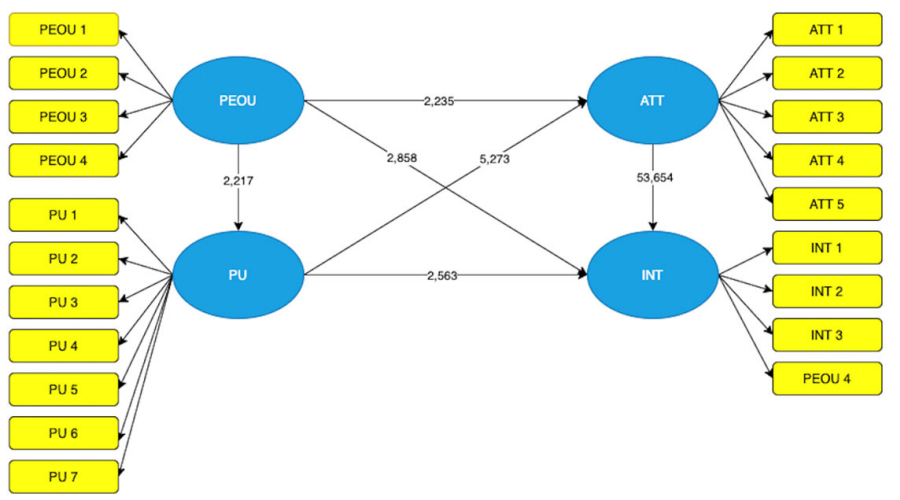

Fig. 2. Outer Model

In the inner model analysis, it must be carried out with the bootstrapping stage, namely by randomly multiplying the research sample from 170 samples to 500 samples to obtain the research results below.

Table 3

The results of path analysis

\begin{tabular}{cccc}
\hline Variables & Original Sample (O) & T Statistics & P Values \\
\hline H1 & 0.151 & 2.235 & 2.563 \\
H2 & 0.175 & 2.858 & 0.011 \\
H3 & 0.280 & 5.273 & 53.004 \\
H4 & 0.394 & 0.000 & 0.000 \\
H6 & 0.898 & 0.0217 \\
\hline
\end{tabular}


Furthermore, Table 3 direct effect coefficient shows that the variable perceived ease of use (PEOU) has a positive and significant effect on attitude (ATT). The regression results have a t-statistic value of 2,235 with a significance level of 0.026 , smaller than the significance level of 0.05 . Therefore, the better the perceived ease of use, the better it will maximize attitude. The perceived usefulness (PU) has a positive and significant effect on intention (INT). The regression result has a t-statistic value of 2.858 with a significance level of 0.004 , which is smaller than the significance level of 0.05 . Therefore, the better the perceived usefulness, the better it will maximize intention. The perceived ease of use (PEOU) has a positive and significant effect on intention (INT). The regression results have a t-statistic value of 2.563 with a significance level of 0.011 , smaller than the significance level of 0.05 . Therefore, the better the perceived ease of use, the more maximizing intention. Perceived usefulness variable (PU) has a positive and significant effect on attitude (ATT). The regression results have a t-statistic value of 5.273 with a significance level of 0.000 , smaller than the significance level of 0.05 . Therefore, the better the perceived usefulness will further maximize attitude. Attitude (ATT) has a positive and significant effect on intention (INT). The regression results have a t-statistic value of 53,654 with a significance level of 0,000 , smaller than the significance level of 0.05 . Therefore, the more the attitude is, the higher the intention will be. perceived ease of use (PEOU) has a positive and significant effect on perceived usefulness (PU). The regression results have a t-statistic value of 2,217 with a significance level of 0,000 , smaller than the significance level of 0.05 . Therefore, the more perceived ease of use the higher the perceived usefulness will be. There are many service program facilities provided by BPJS, such as health care insurance, work accident insurance programs, death benefits, and old-age or pension programs. All these programs are very profitable if followed by workers, especially pension funds are future assets that are expected by many people. There is also a special fund given to workers in the construction sector that comes from the construction services program. The construction service program is divided into a variety of services. Various kinds of services, namely services for construction implementers, consulting services on interesting construction works, as well as construction planning consulting service programs. The E-Payment system has been proven to make it easier for BPJS members to make payments so that BPJS cash flow income will not be hampered due to difficulties in payment.

\section{Conclusion}

The results of research conducted that all hypotheses proposed in this study were accepted, especially the biggest influence was found on the attitude variable towards intention in the use of the BPJS e-payment system in Indonesia. Electronic Payment System (EPS) BPJS strives to create a social security system that is transparent and accountable to BPJS Employment participants. In addition, the payment of dues is easier because it is separate and depends on what program is being paid. Perceived ease of use and perceived usefulness have a significant influence on attitudes and intentions in using the BPJS e-payment system, meaning that the ease and function of e-payments affects people to adopt this digital payment.

\section{References}

Adila, T. M., Bintang, W. S., Ikhsan, R. B., \& Fahlevi, M. (2020). Instagram as information in developing purchase intentions: The role of social E-wom and brand attitude. Proceedings of 2020 International Conference on Information Management and Technology, ICIMTech 2020. https://doi.org/10.1109/ICIMTech50083.2020.9211151

Ajzen, I. (1991). The theory of planned behavior. Organizational Behavior and Human Decision Processes, 50(2), $179-211$. https://doi.org/10.1016/0749-5978(91)90020-T

Arts, J. W. C., Frambach, R. T., \& Bijmolt, T. H. A. (2011). Generalizations on consumer innovation adoption: A metaanalysis on drivers of intention and behavior. International Journal of Research in Marketing, 28(2), 134-144. https://doi.org/10.1016/j.ijresmar.2010.11.002

Azam, A. (2015). Continuance intention model for mobile banking. International Journal of Electronic Finance, 8(2-4), 169188. https://doi.org/10.1504/IJEF.2015.070534

Bagla, R. K., \& Sancheti, V. (2018). Gaps in customer satisfaction with digital wallets: Challenge for sustainability. Journal of Management Development, 37(6), 442-451. https://doi.org/10.1108/JMD-04-2017-0144

Cao, X., Yu, L., Liu, Z., Gong, M., \& Adeel, L. (2018). Understanding Mobile Payment Users' Continuance Intention: A Trust Transfer Perspective. Internet Research, 28(2), 456-476. https://doi.org/10.1108/IntR-11-2016-0359

Casaló, L. V, Flavián, C., \& Ibáñez-Sánchez, S. (2020). Influencers on Instagram: Antecedents and consequences of opinion leadership. Journal of Business Research, 117, 510-519. https://doi.org/10.1016/j.jbusres.2018.07.005

Chawla, D., \& Joshi, H. (2020). The moderating role of gender and age in the adoption of mobile wallet. Foresight, 22(4), 483-504. https://doi.org/10.1108/FS-11-2019-0094

Chen, S. C. (2012). To use or not to use: Understanding the factors affecting continuance intention of mobile banking. International Journal of Mobile Communications, 10(5), 490-507. https://doi.org/10.1504/IJMC.2012.048883

Davis, F. D. (1989). Perceived Usefulness, Perceived Ease of Use, and User Acceptance of Information Technology. MIS Quarterly, 13(3), 319-340. https://doi.org/10.2307/249008

Djakasaputra, A., Wijaya, O., Utama, A., Yohana, C., Romadhoni, B., \& Fahlevi, M. (2021). Empirical study of Indonesian SMEs sales performance in digital era: The role of quality service and digital marketing. International Journal of Data and Network Science, 5(3), 303-310.

Fahlevi, M. (2020). Mobile applications for health management in Indonesia. Proceedings of 2020 International Conference on Information Management and Technology, ICIMTech 2020. https://doi.org/10.1109/ICIMTech50083.2020.9211243

Fahlevi, M. (2021a). Corporate branding in banking environment: Evidence from acquisition process. $729(1), 012130$.

Fahlevi, M. (2021b). Mediating effect of motivation on employees' performance in a private hospital, Indonesia. 729(1), 012001.

Fahlevi, M. (2021c). Online consumer behaviour and its relationship to website atmospheric induced flow: Insights into 
online travel agencies in Indonesia. 729(1), 012114.

Hatzakis, E. D. M., Nair, S. K., \& Pinedo, M. (2010). Operations in Financial Services-An Overview. Production and Operations Management, 19(6), 633-664. https://doi.org/10.1111/j.1937-5956.2010.01163.x

Huang, C., \& Kao, Y. (2015). UTAUT2 Based Predictions of Factors Influencing the Technology Acceptance of Phablets by DNP. 2015.

Istan, M., Husainah, N., Murniyanto, M., Suganda, A., Siswanti, I., \& Fahlevi, M. (2021). The effects of production and operational costs, capital structure and company growth on the profitability: Evidence from manufacturing industry. Accounting, 7(7), 1725-1730.

Kai-ming au, A., \& Enderwick, P. (2000). A cognitive model on attitude towards technology adoption. Journal of Managerial Psychology, 15(4), 266-282. https://doi.org/10.1108/02683940010330957

Khalifa, M., \& Limayem, M. (2003). Drivers of Internet shopping. Communications of the ACM, 46(12), $233-239$.

Kumar, A., Adlakaha, A., \& Mukherjee, K. (2018). The effect of perceived security and grievance redressal on continuance intention to use M-wallets in a developing country. International Journal of Bank Marketing, 36(7), 1170-1189. https://doi.org/10.1108/IJBM-04-2017-0077

Lee, H. J., Cho, H. J., Xu, W., \& Fairhurst, A. (2010). The influence of consumer traits and demographics on intention to use retail self-service checkouts. Marketing Intelligence and Planning, 28(1), 46-58. https://doi.org/10.1108/02634501011014606

Lin, T. C., \& Chen, C. J. (2012). Validating the satisfaction and continuance intention of e-learning systems: Combining tam and is success models. International Journal of Distance Education Technologies, 10(1), $44-54$. https://doi.org/10.4018/jdet.2012010103

Liu, J., Kauffman, R. J., \& Ma, D. (2015). Competition, cooperation, and regulation: Understanding the evolution of the mobile payments technology ecosystem. Electronic Commerce Research and Applications, 14(5), 372-391. https://doi.org/10.1016/j.elerap.2015.03.003

Madan, K., \& Yadav, R. (2016). Behavioural intention to adopt mobile wallet: A developing country perspective. Journal of Indian Business Research, 8(3), 227-244. https://doi.org/10.1108/JIBR-10-2015-0112

Naim, M. F., \& Lenkla, U. (2016). Knowledge sharing as an intervention for Gen Y employees' intention to stay. Industrial and Commercial Training. https://doi.org/10.1108/ICT-01-2015-0011

Nursalam. (2008). Konsep dan Penerapan Metodologi Penelitian Ilmu Keperawatan. Salemba Medika.

Permana, F., Wicaksono, Z., Kurniawan, C., Abdullah, A., \& Ruchjana, B. (2021). Perception analysis of the Indonesian society on twitter social media on the increase in BPJS kesehatan contribution in the Covid 19 pandemic era. 1722(1), 012022.

Ramadan, R., \& Aita, J. (2018). A model of mobile payment usage among Arab consumers. International Journal of Bank Marketing, 36(7), 1213-1234. https://doi.org/10.1108/IJBM-05-2017-0080

Ratnawati, A., bin Mislan Cokrohadisumarto, W., \& Kholis, N. (2020). Improving the satisfaction and loyalty of BPJS healthcare in Indonesia: A Sharia perspective. Journal of Islamic Marketing.

Sahir, S., Fahlevi, M., Kasbuntoro, K., \& Sutia, S. (2021). Effect of halal food management system certification on buying interest of Indonesian consumer goods. Uncertain Supply Chain Management, 9(3), 731-738.

Sahir, S. H., Sugito, S., Hasibuan, A., \& Fahlevi, M. (2021). Customer Experience Management: The Online Travel Agencies in Indonesia. ICIC Express Letters Part B: Applications, 12(4), 369-375.

Saunders, M., Lewis, P., \& Thornhill, A. (2009). Research Methods for Business Students (5th ed.). Prentice Hall.

Shin, D. H. (2009). Towards an understanding of the consumer acceptance of mobile wallet. Computers in Human Behavior, 25(6), 1343-1354. https://doi.org/10.1016/j.chb.2009.06.001

Shittu, T., \& Gamabri, I. (2013). Students' Attitude and Behavioural Intention on Adoption of Internet for Learning among Al-Hikmah University Students in Nigeria: A Test of Technology Acceptance Model Students 'Attitude and Behavioural Intention on Adoption of Internet for Learning am. December 2015.

Singh, N., Srivastava, S., \& Sinha, N. (2017). Consumer preference and satisfaction of M-wallets: A study on North Indian consumers. International Journal of Bank Marketing, 35(6), 944-965. https://doi.org/10.1108/IJBM-06-2016-0086

Sreelakshmi, C., \& Prathap, S. K. (2020). Continuance adoption of mobile-based payments in Covid-19 context: An integrated framework of health belief model and expectation confirmation model. International Journal of Pervasive Computing and Communications.

Venkatesh, V., Morris, M. G., Davis, G. B., \& Davis, F. D. (2003). User acceptance of information technology: Toward a unified view. MIS Quarterly, 425-478.

We Are Social \& Hootsuite. (2020). Digital 2020: Global Digital Overview. In Global Digital Insights. https://datareportal.com/reports/digital-2020-global-digital-overview

Yousafzai, S. Y., Pallister, J. G., \& Foxall, G. R. (2003). A Proposed Model of E-Trust for Electronic Banking. Technovation, 23(11), 847-860. https://doi.org/10.1016/S0166-4972(03)00130-5

Yustisia, T. P. (2014). Panduan resmi memperoleh jaminan kesehatan dari BPJS. VisiMedia. 
(C) 2021 by the authors; licensee Growing Science, Canada. This is an open access article distributed under the terms and conditions of the Creative Commons Attribution (CC-BY) license (http://creativecommons.org/licenses/by/4.0/). 